\title{
Using Agriculture for Development: Supply- and demand-side approaches*
}

\author{
Alain de Janvry \\ Elisabeth SADOUlet
}

Alain de Janvry, Professor of Agricultural and Resource Economics and Public Policy, UC Berkeley; Senior Fellow, FERDI. esadoulet@berkeley.edu

Elisabeth Sadoulet, Professor of Agricultural and Resource Economics, UC Berkeley; Senior Fellow, FERDI. esadoulet@berkeley.edu

\section{Abstract}

For most poor countries of today, using agriculture for development is widely recognized as a promising strategy. Yet, in these countries, investment in agriculture has mostly been lagging relative to international norms and recommendations. Current wisdom on how to use agriculture for development is that it requires asset building for smallholder farmers, productivity growth in staple foods, an agricultural transformation (diversification of farming systems toward high value crops), and a rural transformation (value addition through rural non-farm activities linked to agriculture). This sequence has too often been hampered by extensive market and government failures. We outline a theory of change where the removal of market and government failures to use this Agriculture for Development strategy can be addressed through two contrasted and complementary approaches. One is from the "supplyside" where public and social agents (governments, international and bilateral development agencies, NGOs, donors) intervene to help farmers overcome the major constraints to adoption: liquidity, risk, information, and access to markets.

Key words: staple foods, agricultural transformation, rural transformation, adoption constraints, value chain development.

Acknowledgments: We are indebted to our colleagues and associates Craig McIntosh, Derek Byerlee, Jeremy Magruder, Johan Swinnen, Karen Macours, Kyle Emerick, Leah Bridle, Richard Caldwell, Sarah Boettiger, and Tanguy Bernard for helpful comments and suggestions in the elaboration of this development review. 

The other is from the "demand-side" where private agents (entrepreneurs, producer orgaizations) create incentives for smallholder farmers to modernize through contracting and vertical coordination in value chains. We review the extensive literature that has explored ways of using Agriculture for Development through these two approaches. We conclude by noting that the supply-side approach has benefited from extensive research but met with limited success. The demand-side approach has promise, but received insufficient attention and is in need of additional rigorous research which we outline.

\section{Introduction}

Successful productivity growth in agriculture has been the source of early development and subsequent structural transformation and industrialization in most of today's high income countries. This has been amply documented by the work of historians such as Bairoch (1973) who analyzed at the Western industrialization experience, cascading from England in the mid1700s, to France and Germany around 1820, the United States and Russia in the mid-1800s, and finally Japan with restauration of the Meiji emperors in 1880. Following WWII, agriculture has similarly been the engine of growth and transformation for the Asian industrialization miracles in Taiwan, South Korea, China, and Vietnam (Mellor, 1995). In all these countries, an agricultural revolution preceded a subsequent industrial take-off, typically by something like a half century. Agriculture has also fulfilled an important role in facilitating industrialization in countries like India, Brazil, and Chile (Mellor, 1995; Bustos et al., 2016).

Agriculture remains today the expected engine of growth for the "agriculture-based countries", those countries with a high contribution of agriculture to GDP growth and a high share of their poor in the rural sector (World Bank, 2007). These are also countries where the farm population is importantly composed of smallholder farmers (SHF), in some cases exclusively (e.g., Malawi, Rwanda) and in others coexisting with larger commercial farms (e.g., Senegal, Mozambique). In both cases, agricultural growth importantly requires modernization of the operation of SHFs. With labor-intensive industrialization increasingly compromised by robotization and the re-shoring of industries toward the industrialized countries (Rodrik, 2015), agriculture with agroindustry and the associated linkages to services and non-tradable consumption has been heralded as a potentially effective strategy for GDP growth in these countries (Stiglitz, 2018; Page, 2018). This includes most of the Sub-Saharan Africa (SSA) countries. This approach is a major departure from the classical structural transformation approach based on labor-intensive industrialization advocated in the dual economy models (Lewis, 1954).

The World Development Report Agriculture for Development's (World Bank, 2007) main message was that agriculture-based countries should invest more in agriculture in order to fully capture its potential for growth and poverty reduction. Following the world food crisis of 2008, there was a short-term positive response by governments, international organizations, and the donor community with a sharp increase in investment in agriculture. The number of countries meeting the CAADEP (Comprehensive Africa Agriculture Development Program) goal of 
allocating at least $10 \%$ of government expenditures to agriculture increased from 3 in 2007 to 10 in 2009. Overseas development assistance to agriculture increased by $60 \%$ between 2007 and 2009. But this response has not been sustained. In 2014 (latest data) only 2 SSA countries (Malawi and Mozambique) out of 43 met the CAADEP goal. The modal SSA country spends only $5 \%$ of its public expenditures on agriculture. No SSA country spends a percentage of its public budget on agriculture that reaches the percentage contribution of agriculture to GDP, and $75 \%$ of the countries spend less than half that percentage (Goyal and Nash, 2016). CAADEP also set a goal for public spending on agricultural Research-and-Development to reach $1 \%$ of agricultural GDP. Returns to investing in agricultural research are typically significantly in excess of cost relative to other public programs, indicating under-investment (Alston et al., 2009). This takes extreme forms in SSA where investment is by far the lowest among regions and has been declining over the last decade. In 2011, only six countries (Swaziland, Cabo Verde, South Africa, Botswana, Namibia, and Mauritius) met the CAADEP research goal (IFPRI, 2018). With failure to invest in agriculture, the yield gap on cereals has continued to increase between SSA and other regions of the world. This gap is correlated with a growing chemical fertilizer gap and a large deficit in irrigation. Today, the World Development Report's main message continues to be advocated by international development organizations such as the World Bank, the Food and Agriculture Organization, and the International Fund for Agricultural Development (Goyal and Nash, 2016; IFAD, 2016). This is motivated by the observation that $51 \%$ of the world extreme poor live in SSA, a share that continues to rise, and $78 \%$ of the world extreme poor work in agriculture in spite of rapid urbanization. Success in using Agriculture for Development is thus essential to meet the Sustainable Development Goals on poverty and hunger.

In the current global economic context for the SSA countries, investing in agriculture where the poor work has proven more effective for poverty reduction than taking the poor out of agriculture and to an urban-industrial environment through a Lewis (1954)-type structural transformation. Research shows that the poor are not found in agriculture due to adverse selection. Poverty reduction, where it has happened, has been more effective through productivity growth where the poor work (in agriculture and rural areas) than through structural transformation (Christiaensen and Todo, 2014; Rodrik et al., 2016). A Solow-type decomposition of sources of growth shows that agricultural output growth in SSA in the 19852012 period originated for $63 \%$ from area expansion compared to $8 \%$ from factor deepening and $29 \%$ from productivity growth (Goyal and Nash, 2016). This is not sustainable due to an effective land constraint and declining farm size in most countries as a consequence of rapid population growth. Take Malawi as an example where agricultural land for households engaged in agricultural production fell from 2.3 acres in 2004, to 1.8 in 2010, and 1.4 in 2016 (de Janvry, Duquennois, and Sadoulet, 2018). Productivity growth and factor deepening consequently have to be the main sources of growth in SSA agriculture as in the rest of the developing world where they account for $83 \%$ of agricultural output growth.

This opinion on the role of agriculture for development is far from universally shared in the development community. Gollin et al. (2014) and Collier and Dercon (2015) have argued that rural poverty reduction has to come from employment creation in the urban-industrial environment and a structural transformation of the economy. As seen above, governments have correspondingly not invested public resources in agriculture to the recommended levels. Hence the puzzle in using agriculture for development is: why has the World Development Report/CAADEP recommendation not been followed? We argue here that it is because the mainly supply-side approach used for implementation has proved insufficiently effective, and needs to be complemented for this by a more explicit demand-side approach. 
There are African countries to look at for successful progress toward productivity growth in staple foods (Ethiopia in maize for the domestic market) and a rural transformation (Morocco exports of high value horticultural products and fruit to Europe; Ghana and Côte d'Ivoire cocoa exports; Ethiopia exports of sesame and cut flowers) (Boettiger et al., 2017). Chemical fertilizer use is overall low (16 kg per ha of arable land vs. 158 in South Asia and 344 in East Asia and the Pacific), but uneven across countries. The LSMS-ISA data show that the share of cultivating households using chemical fertilizer reaches $77 \%$ in Malawi, 56\% in Ethiopia, and $41 \%$ in Nigeria, while remaining at $17 \%$ in Niger and Tanzania, and 3\% in Uganda (Christiaensen, 2017). Rural transformation is accompanied by land concentration in medium farms (5 to 100 hectares) in countries like Kenya (where they control $20 \%$ of total farm land), Ghana (32\%), Tanzania (39\%), and Zambia (50\%) (Jayne et al., 2018). These farms are typically mechanized and owned by well-educated urban-based professionals who can be effective agents for technology adoption. These various success stories show that using agriculture for development can be done, but has not yet been sufficient to overcome aggregate rising gaps in yields between SSA and the rest of the world.

\section{The Agriculture for Development sequence}

While there has been limited success with raising public expenditures on agriculture, there has been considerable progress with data collection and with rigorous experimentation on how to promote the modernization of agriculture. We consequently know a lot more today about how to use agriculture for development than we did ten years ago, even though this knowledge has most often not been put into practice in the desirable form and to the desirable degree. It is consequently important to start by reviewing what we have learned.

The main argument that has been used in support of the need for a structural transformation as the mechanism to grow and reduce poverty is that there is a large labor productivity gap between agriculture and non-agriculture (Gollin et al., 2014). An important observation, however, based on the LSMS-ISA data for SSA is that while the gap in labor productivity per person per year between non-agriculture and agriculture is indeed large, the gap in labor productivity per hour worked is relatively small (McCullough, 2017). In other words, when agricultural workers do work, their labor productivity is not very different from that of nonagricultural workers. What this suggests is that there is a deficit in work opportunities for agricultural vs. non-agricultural workers that creates an income gap between the two categories of workers. 


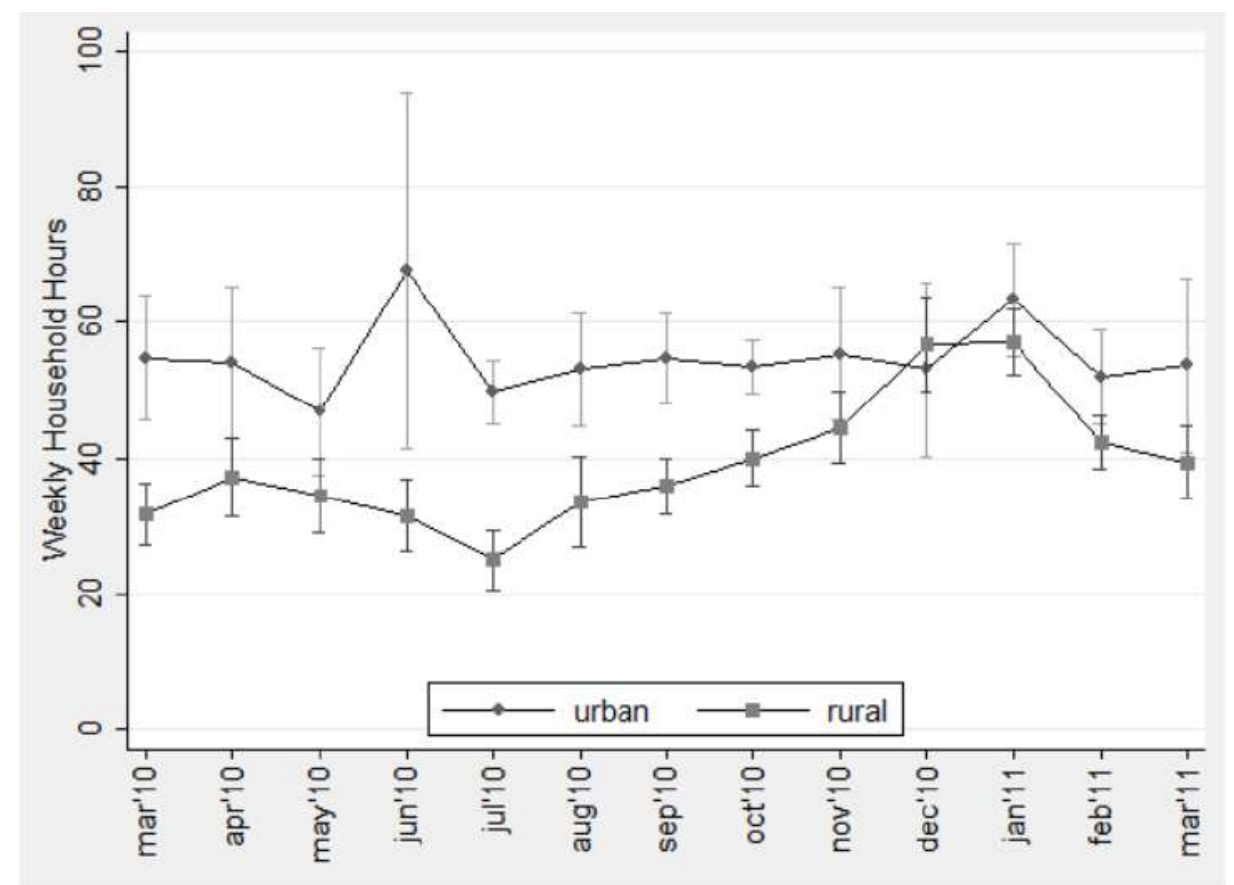

Figure 1. Urban and rural household labor calendars in Malawi

Source: de Janvry, Duquennois, and Sadoulet, 2018

Because households engage in a multiplicity of sectoral activities, the relevant contrast in labor productivity is not between agriculture and non-agriculture, but between rural and urban households, with rural households typically principally engaged in agriculture. Looking at labor calendars for rural and urban households in Malawi in Figure 1, we see that weekly household hours worked are not different for rural and urban households at peak labor time, which corresponds to the planting season in December and January (de Janvry, Duquennois, and Sadoulet, 2018). During the rest of the year, there are much less employment opportunities for rural than urban households, with the former working about half the time worked by urban households during the low season (June and July). Lack of labor smoothing across months can thus be a major cause of income differentials between rural and urban households. Measuring annual labor productivity as median household real consumption per capita, rural households are at $57 \%$ of individuals in urban households. When this is measured not per year but per hour worked, rural households are at $81 \%$ of individuals in urban households.

With high urban unemployment in Malawi limiting the option of reducing rural poverty through permanent or seasonal rural-urban migration, this suggests that a key instrument for rural poverty reduction is to have less idle time for land and labor throughout the monthly calendar. For Bangladesh, Lagakos et al. (2018) proposed filling labor calendars for rural households through migration to cities during the lean season. When this option is not available due to high urban unemployment filling and smoothing labor calendars in rural areas becomes a key dimension of poverty reduction. This can involve employment both in agriculture with more diversified farming systems and in the local rural non-farm economy. This is the purpose of the agricultural and rural transformations that are important in redefining how to use agriculture for development. 


\begin{tabular}{|lc|}
\hline Steps & Processes \\
\hline Asset building & $\begin{array}{c}\text { Access to land and human capital for the } \\
\text { landless and SHF }\end{array}$ \\
\hline Green Revolution & $\begin{array}{c}\text { Adoption/diffusion of new seeds and fertilizers } \\
\text { for staple crops }\end{array}$ \\
\hline Agricultural Transformation & $\begin{array}{c}\text { Access to water for irrigation } \\
\text { Ag diversification toward high value crops } \\
\text { Development of value chains and contracting }\end{array}$ \\
\hline Rural Transformation & $\begin{array}{l}\text { Mechanization and land concentration } \\
\text { Development of land and labor markets } \\
\text { Growth of the rural non-farm economy }\end{array}$ \\
\hline Structural Transformation & Rural-urban migration \\
& Urban-based industrialization and services \\
\hline
\end{tabular}

Table 1. The Agriculture for Development sequence

Based on work done for the IFAD (2016) Rural Development Report led by Binswanger, for China by Huang (2016), by BRAC on graduating the ultra-poor out of poverty (Banerjee et al., 2015a), for the Gates Foundation by Boettiger et al. (2017), and for the ATAI project (ATAI, 2018), a strategy of using agriculture for development would involve the following five steps: Asset building, Green Revolution, Agricultural Transformation, Rural Transformation, and ultimately Structural Transformation as described in Table 1. We refer to this strategy as the Agriculture for Development sequence.

Minimum asset endowments for SHF under the form of land, capital, health, knowledge and skills, and social capital are needed to initiate production for the market and participation in a value chain. This corresponds to minimum capital endowments to get started in production in farm household models such as Eswaran and Kotwal's (1986), and to asset thresholds to escape poverty traps in Barrett and Carter (2012). The BRAC graduation model for the rural ultrapoor thus importantly starts with achieving minimum asset thresholds for households to engage in self-employment in agriculture (Banerjee et al., 2015a), with rigorous impact evaluations demonstrating success in raising household consumption in five of six case countries. Evaluation with a randomized experiment of a BRAC credit program for landless workers and SHF in Bangladesh shows that loans can be used to achieve minimum asset endowments by renting land and selecting more favorable fixed rent over sharecropping contracts (Das et al., 2019).

The Green Revolution, whereby productivity growth is achieved in staple crops through the adoption and diffusion of high yielding variety seeds and fertilizers is the initial step in agricultural modernization. It has been actively pursued to achieve food security and is a learning ground for the subsequent transformations of agriculture and rural areas. It has been a major success of the Consultative Group in International Agricultural Research (Dalrymple, 2008) and is still an ongoing effort in Sub-Saharan Africa and Eastern India.

A key objective of the Agricultural Transformation is to fill in rural households' labor calendars over as much of the year as possible through multiple cropping (diversification in agriculture)-which typically requires water control to cultivate land in the dry season--, the development of value chains for new crops, and contracting among agents in these value chains. An example is the introduction of short duration rice varieties in Bangladesh that frees the land for an 
additional crop, typically high value products such as potatoes and onions, between rainy season and dry season rice crops. This makes an important contribution to filling land and labor calendars and to reducing the length of the hungry season (Dar et al., 2019). Because the Agricultural Transformation implies diversification of farming systems, it is a key element of national food security strategies where diverse diets, including perishable goods such as fruits and vegetables, dairy products, and meats that are less traded than staple foods, are an important element of healthy diets (Dewey, 2017).

SHFs are engaged in value chains that define the way they relate to markets. Value chains for agricultural products link farmers backward to their input and technology suppliers and forward to intermediaries, processors, and ultimately consumers (Reardon et al., 2009; Swinnen et al., 2015). Relations within value chains often take the form of contractual arrangements. Induced by income gains for consumers, urbanization, and globalization, there has been in recent years a rapid development of value chains not only for low-value staple food crops, but also for medium-value traditional domestic consumption and export crops, and high-value nontraditional export crops. Their structure can take a wide variety of forms in linking SHF to consumers, ranging from traditional spot markets to elaborate contract farming, productive alliances (where contracts are with producer organizations), and out-grower schemes (Byerlee and Haggblade, 2013). Contracts can be "resource-providing", thus contributing to solve market and institutional failures for participating SHFs.

A key objective of the Rural Transformation is to give access to smallholder households to sources of income beyond agriculture. In Ghana, income derived from the rural non-farm economy (including seasonal migration) for rural households is about $40 \%$ of total income, a share that increases as land endowments fall (World Bank, 2007). It is indeed the case that, with land limitations, smallholder households rarely exit poverty with agriculture alone. A rural transformation requires the development of land markets (to allow for gradual land consolidation and mechanization) and of labor markets (with different members of the household usually specializing in farm or non-farm activities rather than switching activities over the labor calendar; see de Janvry, Duquennois, and Sadoulet, 2018, for Malawi). This process will typically happen first in the more favorable areas where a rural non-farm economy linked to agriculture can develop through forward, backward, and final demand linkages. It corresponds to the Agriculture Demand-Led Industrialization strategy advocated by Adelman (1984) and Mellor (1995) that is actively pursued in countries such as Ethiopia and Rwanda, and through CAADP in much of Sub-Saharan Africa.

\section{A theory of change for the Agriculture for Development sequence}

In vast regions of Sub-Saharan Africa and South Asia, the unfolding of an Agriculture for Development sequence has been held back by multiple obstacles that originate in asset deficits, market failures, and institutional deficiencies (World Bank, 2007; Goyal and Nash, 2016). This results in constraints to adoption of new technologies and lack of development of inclusive value chains. These failures may result in (1) lack of profitability of innovations for particular SHFs given their specific circumstances, (2) lack of local availability of the innovations in spite of potential profitability, and (3) constraints to adoption in spite of potential profitability and availability. These constraints concern most particularly lack of access to sources of 
liquidity such as credit and savings, risk and lack of access to risk-reducing instruments such as insurance and emergency credit lines, lack of access to information about the existence of new technology and how to use it, and lack of access to input and output markets due to high transaction costs such as poor infrastructure and collusion of traders in local markets. The Agriculture for Development sequence is thus particularly multidimensional and difficult to implement.

There are basically two contrasted approaches to potentially overcoming the problems that obstruct an Agriculture for Development sequence. The first consists in focusing on particular groups of farmers and addressing each of the problems in their own shapes and forms that affect them in modernizing. We can label this a "supply-side" approach to modernization and transformations. It consists in securing the existence and profitability of innovations, ensuring their local availability, and then overcoming each of the four major constraints to demand and adoption through either better technology or through institutional innovations (Magruder, 2018; Bridle et al., 2019). The agents for this approach are principally public and social such as governments, development agencies, NGOs, and donors. The second consists in creating incentives for SHF to modernize by building value chains for the particular product, and managing vertical (contracts, stakeholder dialogue) and horizontal (producer organizations) coordination within the value chains to overcome the profitability-availability-constraints obstacles as they apply to inclusion and competitiveness of SHF in the value chain. This is a "demand-side" approach to modernization and transformations. It consists in creating the demand for innovations in order to establish SHF competitiveness within a value chain, and then securing the existence, availability, and conditions for adoption of innovations. The approach thus requires both value chain development and value chain inclusion of SHFs. In this case, the agents are principally private such as enterprises and producer organizations for contracting, and lead firms, multi-stakeholder platforms, and benevolent agents for coordination. Public-private partnerships can be found among both supply- and demand-side initiatives.

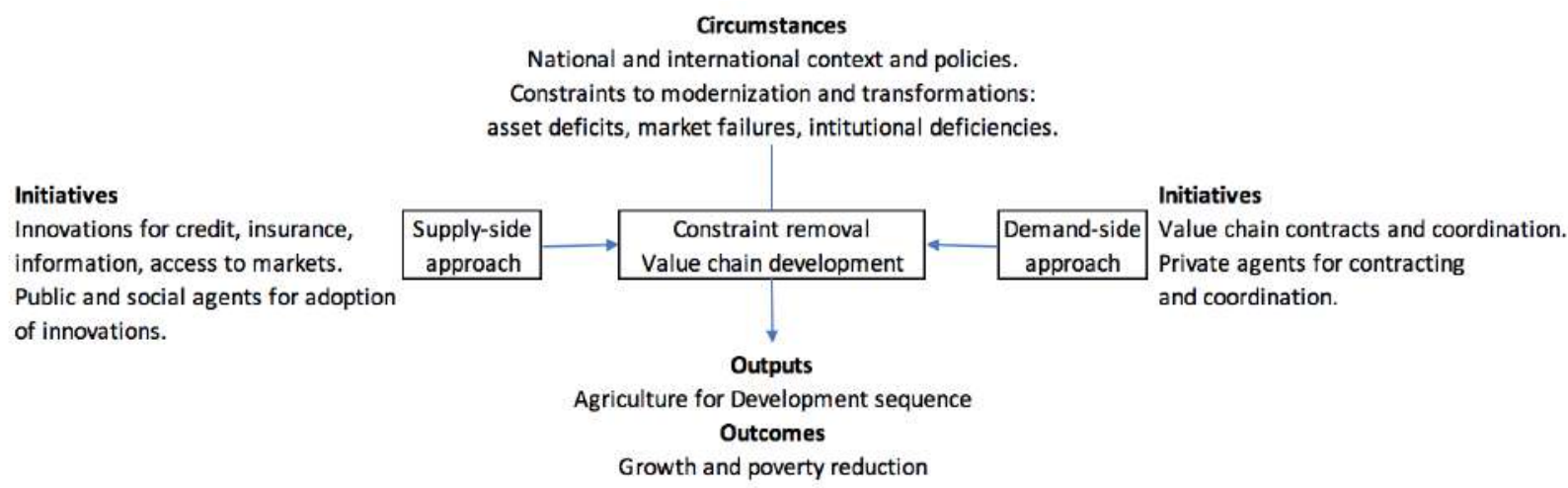

\section{Figure 2. Theory of change for unleashing an Agriculture for Development sequence: Supply-side and Demand-side approaches}

The theory of change we use in this review paper is represented in Figure 2. Circumstances for unleashing an Agriculture for Development sequence include the national and international context and policies, deficits in access to assets, and market and government failures that affect SHF. Approaches to modernization can follow a supply-side or a demand-side approach, in each case with specific agents engaging in the corresponding activities. Desired outputs are 
productivity growth in staple foods and Agricultural and Rural Transformations; desired outcomes are growth and poverty reduction. In what follows, we review each of these approaches in turn. Both have been extensively used and analyzed, yet belong to somewhat separate traditions in spite of obvious complementarity.

\section{Lessons from studies addressing Agriculture for Development from the supply side}

Technological innovation are first analyzed in experimental plots, usually for yield and resilience to specific shocks. But this does not tell us whether the innovation is likely to be adopted by SHF. Analysis of the adoption problem should start with verification that the innovation is indeed profitable for the intended SHF under their own circumstances, objectives, and capacities. Measuring profitability in farmers' plots is however very difficult (Foster and Rosenzweig, 2010). There are data problems in observing family labor time and definitional problems in establishing the opportunity cost for family labor and self-provided inputs. Conditions also vary year-to-year due to weather conditions, with only short time series to observe how climate affects outcomes, made even more difficult to interpret with climate change. And there are many unobservable conditions and complementary factors that affect profitability and compromise the external validity of any measurement made at a particular time and place. An alternative approach is to verify profitability without measuring it. Some among the best endowed and best located farmers have to be able to make sustained use of the innovation for the innovation to have adoption potential by others under current (or modifiable) market, policy, and complementary input conditions. This can be established by observation, experimentation, or simulation.

Once the innovation is proven profitable and is locally available, its adoption may still be hampered by constraints facing SHF in accessing liquidity, risk-reducing instruments, information, and markets. These four categories of constraints have been extensively analyzed using in particular randomized control trials to identify their causal relations to adoption (ATAI, 2018; Bridle et al., 2019). These studies typically seek to identify ways of overcoming these constraints that could be implemented by governments, international organizations, NGOs, and benevolent agents such as philanthropic foundations and corporate social responsibility initiatives.

\section{a. Credit and savings}

Due to seasonality, especially under rainfed farming conditions which is where most of the lag in modernization currently prevails (i.e., in most of Sub-Saharan Africa and Eastern India), there is a lack of correspondence between the timing of agricultural incomes and that of expenditures. As a consequence, the inter-temporal displacement of liquidity through credit and savings appears to be important for farmers to invest in new technologies, purchase inputs, optimize the timing of sales, buy consumption goods, and cover timely expenditures such as school fees.

Financial services for SHFs appear to frequently be ill-designed for their purpose, expensive, excessively risky, and not easily available. Even when they have formal land titles, SHF are typically unwilling to put their land at risk as collateral with a commercial bank, thus acting as "risk constrained" (Boucher et al., 2008). Microfinance products that effectively circumvent the collateral problem by relying on group lending and joint liability tend to be too expensive for the long agricultural cycles (e.g., 24\% interest on BRAC and Grameen Bank loans with 7\% 
inflation in Bangladesh) and have repayment conditions that are typically ill adapted to the timing of farmers' capacity to pay (Burke et al., 2019). Availability of credit from formal sources, both commercial and non-profit, is consequently limited, and SHFs must either selffinance or rely on informal lenders with prohibitive interest rates. Hence, there would appear to exist a largely unresolved liquidity constraint on adoption originating on the supply side of the financial market.

Yet, this is often not the main reason for low adoption which may be on the demand side. Recent field experiments are providing evaluations of interventions aiming at relaxing the liquidity constraint on SHFs, with fertilizer the most commonly used indicator of technology adoption because of its ubiquitous recognition and yet massive underuse. While contexts and interventions vary for these experiments, they surprisingly tend to show that a liquidity constraint is not the reason why a majority of SHFs are under-investing in fertilizers. The main constraint may be instead lack of profitability in adopting fertilizers.

A first category of experiments consists in providing unrestricted access to credit to a defined eligible population, as was done in Morocco (Crépon et al., 2015), Mali (Beaman et al., 2015), and Ethiopia (Tarozzi et al., 2013). While interest rates in these studies were variously subsidized (they were set at $12.5-14.5 \%, 25 \%$, and $12 \%$, respectively), uptake remained low: only $17 \%$ of eligible farmers took a loan in Morocco, 21\% in Mali, and 36\% in Ethiopia. Furthermore, farmers that did take a loan only used a small fraction of the liquidity to increase their expenditures on fertilizer or other agricultural inputs (e.g., input expenditures increased by $11 \%$ in Mali, relative to farmers in the control group that were not offered credit).

Other experiments offered restricted credit that can only be used to purchase agricultural inputs. Such credit displaces the equilibrium allocation of liquidity in favor of the targeted inputs, similarly to what a price discount would do. And yet, uptake remained low. In Malawi input credit (at 27.5\% interest rate for 10 months) for high-yielding maize and groundnuts was taken by $33 \%$ of the farmers (Giné and Yang, 2009).

This low demand for credit thus seems to be reflective of a low demand for the inputs themselves. Low demand for fertilizer is exemplified in two rather extreme experiments. In Mali, Beaman et al. (2015) provided to another group of farmers a pure cash grant, rather than the credit described above. This only increased expenditures on fertilizer by $15 \%$, in comparison with $11 \%$ with a credit that had to be paid for, showing that credit is not the major constraint to adoption. In Mozambique, a group of progressive and well positioned farmers, with good access to extension services and to input and output markets, were offered vouchers with a $75 \%$ discount on fertilizer price, and yet only $28 \%$ of the farmers redeemed their vouchers (Carter et al., 2013).

There are a few experiments that show the importance of well-tailored credit and savings products to support the adoption of profitable innovations by SHF. Two cases exhibit the importance of accounting for the seasonal distribution of farmer income. In Kenya, One Acre Fund offered harvest-time loan at 10\% interest rate with repayment expected 9 months after harvest, collateralized with stored maize. The objective was to allow farmers to avoid selling their harvest at the time of the year where prices are lowest, postponing sale to the period of high prices. $63 \%$ of eligible farmers took the loan (Burke et al. 2019). A similar savings scheme through group-based grain storage was introduced in Kenya. Fifty eight percent of the farmers took-up the product, and were twice as likely to sell maize on the market (Aggarwal et al., 2018b). While these financial products contribute to the households' welfare, and indirectly 
increase the return to agricultural production, there is no evidence that they induced higher adoption of fertilizer or other modern technologies.

These experiments point to the existence of other constraints to fertilizer use. This can be lack of complementary inputs (such as organic fertilizers for soil texture and lime for soil acidity), excessively high risk, or high transaction costs in reaching markets that all make fertilizer use not profitable. These other constraints need to be jointly addressed with credit availability. An example is new financial products such as Risk Contingent Credit--where repayment is insured by an index insurance, where insurance serves as collateral for the loan, and where the insurance premium is paid with loan repayment at the end of the season--that have promise and are under experimentation (Shee et al., 2018). Another example is precision farming where soil testing allows to customize fertilizer recommendations to heterogenous local conditions and to design comprehensive technological packages (Cole and Fernando, 2016).

Conclusion is thus that, in spite of presumptions, credit availability is not the main constraint to fertilizer use for a large majority of SHF in SSA and SA. For them, low fertilizer use is mainly due to low profitability associated with physical, market, and institutional conditions. Interventions to jointly secure the profitability of fertilizers and the availability of welldesigned financial products for their own particular circumstances are necessary for large scale adoption to occur.

\section{b. Risk and Insurance}

Smallholder farmers are exposed to many risks that can put their livelihoods and assets in jeopardy and deter investment. Shocks include weather, plagues, prices, and health. As a consequence, SHF engage in shock-coping adjustments after an adverse event has occurred, and in risk-management strategies in anticipation of shocks difficult to cope with. Both responses are costly. Shock-coping includes dis-saving, emergency borrowing, sale of productive assets, emergency migration, use of child labor by taking children out of school, and postponement of consumption expenditures. Some of these responses can have long-term consequences, particularly when they imply decapitalization of assets, including child human capital and health (Carter and Barrett, 2006; Maccini and Yang, 2009). SHF also engage in risk-management practices. This includes preferring to use low return-low risk traditional technologies, holding large precautionary savings (such as food stocks) and productive assets that are biased toward liquidity (such as animals), and engaging in income diversification at an efficiency cost (Rosenzweig and Wolpin, 1993).

These costly strategies to deal with risk reduce the resources available for investment and technology adoption. Risk exposure also has a direct consequence on the adoption of technologies in reducing their expected return. Thinking of fertilizer, for example, the possibly that drought or flood wipes out the harvest and hence the return to fertilizer discourages its application in the first place (Dercon and Christiaensen, 2011)

The obviously missing piece in the panoply of risk management and risk coping instruments used by smallholder farmers is insurance. Agricultural insurance is common in developed countries, although usually heavily subsidized. For SHF in developing countries, the administrative and implementation costs for agricultural insurance that requires verification of losses by an adjustor are too high to make it cost effective. Index insurance, where payments are triggered by a verifiable local index of rainfall or small area average yield has promise (Carter et al., 2017). Yet, take up has been very low, typically not exceeding 6 to $18 \%$ at market 
price (Schickele, 2016) for multiple reasons including basis risk, lack of trust, liquidity constraints, and limited salience of benefits (Cole et al., 2013)

The question for this paper, however, is whether insurance, when taken, induces farmers to adopt technology. Only a few studies in which the insurance uptake was sufficient permit this analysis. Experimental results for Ghana have shown that farmers that purchased insurance increased their use of chemical inputs by $24 \%$ (Karlan et al., 2014). Mobarak and Rosenzweig (2013) offering a (highly subsidized) insurance service to farmers in India, show that it induced them to replace their use of traditional risk tolerant rice varieties by higher yielding varieties. Cai (2016) shows that a weather insurance policy in China induced tobacco farmers to increase their production of this risky but highly profitable crop by 16 percent and their borrowing by 29 percent.

These experimental results suggest that if one could improve the design and marketing of the insurance product so that uptake could increase, technology adoption may follow. Promising avenues include products with reduced basis risk (higher density of weather stations and better yield predictions using satellite imagery), financial training to help farmers better understand the value of insurance (Cai et al., 2020), group insurance on the presumption that managers have a better understanding of the product than farmers (McIntosh et al., 2018), and combining index insurance with other risk-reducing instruments, including social assistance for large shocks (Carter et al., 2017).

Also promising is to reduce risk through resilient technology such as drought and flood tolerant seed varieties. SwarnaSub1, a superior rice technology with flood resilience properties, is appealing to farmers in flood-prone areas of India. Emerick et al. (2016) show that adoption of Swarna-Sub1 enhances agricultural productivity by crowding in modern inputs (fertilizer) and cultivation practices (more labor intensive planting method), and increasing credit demand. Finally, an innovative financial product introduced by BRAC in Bangladesh is contingent credit lines indexed on events such as flooding (Lane, 2018). This experiment shows that households given pre-approval to take a loan if they experienced flooding in their local area increased investment in risky production practices as part of their risk-management response. Since offering contingent credit lines has little ex-ante cost, the behavioral effect can be very large.

\section{c. Information}

A farmer's decision to adopt a technology relies on his assessment of its value for himself. Hence beyond being aware of the existence (and availability if it needs to be acquired) of the technology, the farmer needs fairly complete information on the specificity of the technology, how to use it or adapt it, and how it would perform in his own context. To take some examples, the adoption of a new variety or management practice requires being aware and informed on their characteristics, associated best practices, and benefits. But even the adoption of fertilizers which are broadly familiar to most farmers, requires reliable information on their quality (Bold et al., 2017) and the very specific quantity and timing of application that depends on local conditions. This learning process is particularly difficult due to the heterogeneity of contexts across farmers (notably spatial heterogeneity of soil quality) and across years (notably because of weather variation) (Tjernström, 2017). The traditional model of public or private sector extension agents faces multiple limitations. In addition to customization of the advice that should be delivered, the sheer number of smallholder farmers and their geographical dispersion limit what a public or private extension service can possibly achieve. In India, for example, 
fewer than $6 \%$ of the agricultural population reports having ever received information from extension services (Cole and Fernando, 2016). In Uganda and Malawi, these numbers are higher (11\% and $50 \%$ in one year, respectively) but still imply receiving a service less than once a year (Ragasa and Niu, 2017; Kabunga et al., 2016).

Given the multitude of smallholder farmers and the limited number of extension agents, extension services have typically focused their efforts on training "contact farmers" and expecting that these entry points in the farming community will circulate (push) information in their social networks, inducing other farmers to adopt (Anderson and Feder, 2007). The idea is to reinforce the process of learning and diffusion of technology from farmers experiencing for themselves to watching others experience the technology (Foster and Rosenzweig, 1995). Recent research has attempted to improve on this model by identifying optimum entry point farmers to maximize the subsequent diffusion of information and adoption. The theory of social networks gives useful clues as to which farmers to potentially select as contact farmers based on their position in the network (Beaman et al., 2018). Other less theoretically based experiments compare the diffusion of the technology through contact farmers selected as "peer" farmers (resembling most others in the community, in particular by gender), large farmers, extension officer-designated farmers, community-designated farmers, members of women's groups, etc. (Emerick and Dar, 2019; BenYishay and Mobarak, 2019; Dar et al., 2019). Results do not converge to a general finding, suggesting that who is a better contact farmer is context specific.

To be good entry points, contact farmers also need to be good experimenters, demonstrating the benefits of the new technology. Finding out who those good demonstrators are in not easy. An interesting idea is that farmers themselves have a better idea of how they will benefit from the new technology. And this should be reflected in their willingness-to-pay to experiment with the new technology (Chassang et al., 2019). Experimentation has shown that incentivizing contact farmers with the payment of bonuses proportional to their success with diffusion of the innovation in their community may be necessary and can be effective (BenYishay and Mobarak, 2019). It remains however unclear whether this recommendation is scalable.

Extension services can be made more effective using ICT technology. Experiments include sending SMS reminders to farmers on agronomic practices (Casaburi et al., 2014) and using SMS to make recommendations customized to farmers' own idiosyncratic soil conditions (Cole and Fernando, 2016). In some specific cases, there may be simple techniques that can substantially improve farmers' ability to obtain information through self-experimentation. An interesting experiment provides farmers with leaf color charts that guide them in their fertilizer doses decisions (Islam, 2014).

The extension models described above rely on what can be called a "push approach", whereby contact farmers are expected to pass information to others in their social networks. There is also potential for a "pull approach" to the diffusion of information through social learning. In this case, information is broadly broadcasted in the community that something is to be learned from informed (contact) farmers. This "buzzing" can motivate farmers to seek information from informed farmers that may be inside or outside their normal social networks. Dar et al. (2019) thus show that "buzzing" through visible demonstration plots that use a counterfactual (so-called "side-to-side" demonstration plots where the next best seed variety for the demonstrating farmer is cultivated next to the new technology) can be just as effective as seeding information through central farmers (in this case large farmers and extension officerselected farmers). Under this approach, farmers know that there is something to be learned and 
they know with whom to engage in conversation to be informed. Banerjee et al. (2018) found a similar result in helping people understand the demonetization process in India: inform selected individuals in the community and widely tell the community who they are to induce information-seeking conversations. The advantage is lower cost (not having to identify who are the best contact farmers in each community) and ability to reach less privileged farmers who do not belong to well informed social networks.

In general, results show that information remains a serious constraint on SHF modernization. Extension services are even more under-funded than Research-and-Development and in need of new approaches that may work. Social learning can be made more efficient by a better choice of contact farmers and giving them high-powered incentives to diffuse information. Social learning can be reversed from push to pull for broader impact. Using IT services such as Digital Green and digital platforms offer interesting new options (Aker, Ghosh, and Burrell, 2016). Innovative approaches in addressing the information problem are in need of conceptualization and experimentation, with significant opportunities to make a large difference on SHF modernization.

\section{d. Access to markets and quality recognition}

Incentives to adopt require good access to well performing markets. In contrast, SHF typically face poor infrastructure and high transaction costs, limited access to information on prices, lack of competition on local markets, and problems with quality recognition for inputs and outputs.

Distance to market and poor infrastructure are major contributors to higher input prices and lower product prices for net sellers, which in turn act as a tax that discourages the adoption of innovations. Aggarwal et al. (2018a) thus show that distance to market is equivalent to a $6 \%$ ad-valorem tax per kilometer for villages in Tanzania. Reducing travel cost by 50\%, which is said to be equivalent to paving rural roads, would in this case increase local maize prices and double fertilizer adoption. Improved infrastructure may however increase or decrease the prices of local crops depending on the competitiveness of local goods with those from further away. For Sierra Leone, Casaburi, Glennester, and Suri (2013) show that improving rural roads lowers prices on rural markets, benefiting consumers and hurting producers. They find that only when cell phone services help traders reach markets further away does improved infrastructure raise local prices, benefiting producers. For teff in Ethiopia, Vendercasteelen et al. (2018) show that proximity to cities increases the price received by farmers as well as the use of fertilizer and improved seed, resulting in higher yields, especially proximity to primary as opposed to secondary cities.

Improved price information can also have mixed effects on farmer welfare. The role of IT services in reducing search costs, lowering local price volatility, raising average producer prices, and lowering consumer prices was observed by Jensen (2007) for fish in India and by Aker (2010) for grains in Niger. Better information on prices was also observed by Svensson and Yanagizawa (2009) in Uganda to have a positive effect on the level of prices received by farmers. However, better price information may have no effect on prices received by farmers if they have no option to sell on these markets and no bargaining power with local merchants (Fafchamps and Minten, 2012).

Local markets may also not be competitive, with the possibility of extensive collusion among merchants as shown by Bergquist (2017) in Kenya using an experiment exogenously varying the number of merchants on local markets with no consequent impact on price. This finding is 
however not supported in an extensive literature review by Dillon and Dambro (2016) who found that local markets in Sub-Saharan Africa overall tend to be competitive.

Finally, quality recognition is a major issue on local markets, even though urban consumers may be willing to pay a price premium for higher quality, particularly for higher phytosanitary standards. Quality recognition via third party certification, as for onions in Senegal, resulted in higher prices for good quality produce and created incentives for farmers to adopt qualityenhancing technology (Bernard et al., 2017). On input markets, Bold et al. (2017) find that there is extensive cheating on the quality of fertilizers, contributing to low adoption in Uganda. An experiment by Hasanain, Khan, and Rezaee (2016) shows that quality recognition in services markets via IT ratings can lead to improved veterinary services for artificial insemination in Pakistan. This was due to increased veterinarian effort once success rates were known to cattle owners.

Lack of quality recognition for domestic production is a major issue for the competitiveness of SHFs with imported food on urban markets. It creates an increasing disconnection between what farmers produce and what urban households consume. The large number of SHFs and aggregation of production by traders high in the value chain prevents creating incentives for farmers to increase the quality of what they produce. This contributes to rising dependency of urban consumers on imported foods and low prices for domestic producers, discouraging technological upgrading.

The frequent poor performance of markets due to high transaction costs, partial transmission of information, frequent lack of competitiveness, and lack of quality recognition remains a major obstacle to profitability and hence to technological upgrading. Addressing these constraints requires not only institutional innovations, but also costly public investments in infrastructure and marketing facilities.

\section{e. A ceiling to adoption}

The supply-side approach to constraint removal and value chain development has helped identify a large number of technological and institutional innovations with potential to enhance adoption. In spite of this, technology adoption and modernization has been modest. As shown by continuously rising cereal yield gaps, and in spite of many local success stories, a global Green Revolution for Africa is still in the waiting. A major difficulty for technology adoption under rainfed conditions is heterogeneity of conditions. At the household level, this applies to three dimensions: farmer circumstances, farmer objectives, and farmer capacity. If these dimensions are immutable or too costly to change, technological innovations must be customized to fit these dimensions.

Farmers' circumstances such as agro-ecological conditions vary widely over short distances and across years in particular regarding rainfall patterns and soil fertility (soil acidity, organic matter). For Zambia, Burke et al. (2017) show that only $8 \%$ of farmers can profit from basal chemical fertilizer applications due to lack of a complementary factor, in this case lime to achieve the desirable level of soil acidity. In Western Kenya, Marenya and Barrett (2009) find that only $55 \%$ of plots can profitably use chemical fertilizers due to lack of a complementary factor, in this case soil organic matter as measured by carbon content. Barghava et al. (2018) similarly find that there is complementarity between soil organic carbon and modern inputs. For adoption to go beyond farmers with complementary factors in place, technological 
innovations must either be customized to fit heterogeneous contextual conditions, or complementary factors must be delivered jointly with the technological innovation.

Farmers' objectives are different from breeders' who typically focus on maximum yields in experimental plots with highly favorable controlled conditions (Laajaj et al., 2018). Farmers maximize profit or utility weighting return and risk. They may also have labor calendar objectives such as labor-saving at peak periods and labor-smoothing in the rest of the year. Labor constraints on farming may come from involvement in rural non-farm economy activities and seasonal migration, requiring to fit farming systems to accommodate complementarities between on- and off-farm labor engagements, including a gender division of tasks. The household will have nutritional objectives if part of the harvest is home consumed, and diversity of diets matter for the choice of farming systems. These specific objectives must feed into the design of new customized technological innovations.

Farmers' capacity may be improved through the acquisition of information and skills, but other dimensions of capacity are fixed factors to which technological innovations must adapt. T.W. Schultz (1964) and Foster and Rosenzweig (2010) famously showed that farmers' education matters for technology adoption. Low skills may reduce the capacity and the speed of learning (Laajaj et al., 2018). Again, limits on capacity must be taken into account on the supply side of technology if it cannot be addressed as a demand-side constraint that can be relaxed. Technology must be kept relatively simple to use. An example is SwarnaSub1 that requires the same agronomic practices as the widely used Swarna rice variety. Another is the leaf color chart to adjust the quantity and timing of fertilizer applications.

It is thus possible that available technology is not adapted to the circumstances and demands of a majority of farmers. Either it has to be adapted to the lack of key complementary factors, or the complementary factors have to be jointly delivered as a technological package. Unless this is done, lack of technological upgrading for a majority of farmers may not be an adoption issue (i.e., a constraint that can be directly addressed) but a supply-side issue concerning the availability of technologies that are profitable and adoptable by a majority of farmers. Lack of investment in Research-and-Development to address the specificity and heterogeneity of SubSaharan conditions noted above adds credibility to this interpretation. This is documented by Pardey et al. (2016) who shows that there is both under-investment in agricultural research in Sub-Saharan Africa as revealed by an estimated average internal rate of return of $42 \%$ for 25 countries over the 1975-2014 period, well in excess the expected return on public investment, and a continuing deterioration of the situation. Goyal and Nash (2016) document a net decapitalization of agriculture Research-and-Development capacity in Sub-Saharan Africa over the last decade.

Conclusion is that an approach to using Agriculture for Development that seeks to remove constraints on adoption of existing technology from the supply side is essential, but likely to hit a low ceiling due to heterogeneity of conditions, lack of complementary factors, and diverse farmers' objectives and capacity. Lack of quality recognition also creates increasing disconnectedness between what farmers produce and what urban consumers demand. A complementary approach to address these issues is development of inclusive value chains and constraint removal starting instead from the demand side.

\section{Lessons from studies addressing Agriculture for Development from the demand side}


A demand-side approach consists in creating incentives for SHF to modernize through their participation in vertically coordinated value chains that provide links to markets for products with a profitable effective demand, while at the same time potentially offering solutions to market and institutional failures. The advantage of a demand-side approach is that it does not predetermine the solution to adoption (the removal of a particular constraint) but seeks instead broad complementarities in the ways of achieving modernization that are specific to the agent in question. Referring to the Byerlee and Haggblade (2013) classification mentioned above, we include under the category of vertically coordinated value chains, resource providing contracts (contract farming, out-grower schemes) and the more complex multi-stakeholder structure. Which elements are included in contracts (credit, technology transfer, input provision, information, training, etc.) and the specific structure and institutional form that vertical coordination will take is endogenous, depending on the particular needs of producers, the endbuyers, and the context of market failures and institutional deficits.

\section{a. Resource providing contracts}

A key element of modern value chains that can result in SHF modernization is implementation of resource-providing (also called interlinked) contracts (Bardhan, 1989; Devaux et al., 2016). Contracts can take on a large variety of forms (Bellemare and Lim, 2018; FARM Foundation, 2018). They can help SHFs overcome market failures (in credit, insurance, and inputs) and government failures (in information and access to markets). For example, a contract in an outgrower scheme with a sugar plantation in Kenya provides index insurance to individual farmers with the premium deducted from harvest-time payment for product delivery (Casaburi and Willis, 2018), providing a rare case of large take-up of index insurance without subsidies. Quality recognition can be an integral part of contracts, for instance inducing higher quality of cocoa production in Sierra Leone (Casaburi and Reed, 2017).

Resource-providing contracts are however typically complex to put into place, implement, and enforce. Contract terms (phytosanitary and quality norms; technological specifications in production) can be difficult for SHFs to respect. This applies for example to supermarkets that demand quality standards approximating international norms. Monopsony power of contracting agents (agribusiness, agro-exporters, supermarkets) can lead to hold-up practices with defaults or delays in payments and lower prices on deliveries. Side-selling by SHFs when the contract price is inferior to the local market price at harvest time can also undermine the enforcement and credibility of contracts. And principal-agent relationships facilitate appropriation by the lead agent, typically the commercial partner in a contract with farmers, of the net social gains created by the contract thus limiting its potential for poverty reduction if there has been no improvement in farmers' bargaining power over surplus. Despite these difficulties, empirical studies tend to show positive benefits of these contracts for SHFs under the form of technology adoption, agricultural transformation, and income and employment gains (see for example the study by Dihel et al., 2018, for Ghana, Kenya, and Zambia). Most available impact studies are however recognized to suffer from selection biases and external validity issues (Bellemare, 2015).

\section{b. Vertical coordination in value chains}

Other institutions are frequently necessary to complement or strengthen a simple contract. For example hold-up risk by the buyer can be resolved through a jointly accepted external 
certification agent. Saenger et al. (2014) show that providing dairy farmers contracted by a large company in Vietnam an independent milk quality assessment induced a $12 \%$ increase in input use, and a significant corresponding increase in output (quantity of milk fat and total solids), ultimately translating into higher welfare for farmers. What is interesting in this case is that, while the company was playing fair with farmers, some of them believed that it was behaving opportunistically in deciding to reject some milk deliveries. Independent certification can thus benefit both the farmers and the company. More generally, quality certification can have a major role in value chain development where phytosanitary standards and other qualitative aspects of produce are essential. Important is for certification to happen low in the value chain, before aggregation of produce makes it impossible to reward individual quality contributions, which is particularly challenging when production originates in thousands of very small farmers (Bernard et al., 2017; Abate and Bernard, 2018). Where quality can be certified early in the value chain, incentives can be created for farmers to invest in quality enhancement, in particular through the adoption of technological change.

Beyond the direct contract between (say) an agro-industry and farmers, arrangements may involve a separate input provider, or a financial actor that will provide credit to the farmers, possibly guaranteed by the agro-industry or the input provider, or a transporter, etc. These arrangements result in value chain models that are quite complex, entailing the need for coordination between multiple stakeholders, sometimes referred to as innovation platforms.

As an example, the Bubaare Innovation Platform in Uganda developed since 2008 the sorghum value chain for the production of baby food and a traditional beverage in a context where most small farmers previously only produced sorghum for their own consumption. The platform includes Huntex Ltd, a large processor selling to supermarkets that invested in storage (a key element for the conservation of the products that could only be afforded with economies of scale) and packages and commercializes the products, credit partners that provide financing to farmers and the processor, the public agricultural research system that developed new high yielding varieties, extensions services that taught farmers improved crop management techniques, local parish governments that set standards for the commercialization of sorghum, and the University of Makerere that helped with technology development. This successful platform registered as a cooperative in 2013 and operates without any further donor intervention, solely relying on membership fees (Kalibwani and Twebaze, 2015).

A different story emerges from Peru, where a value chain was created to market native potatoes produced by SHF to high-income consumers in Lima. Coordination is assumed by a strong intermediary (CAPAC, Cadenas Agricolas Productivas de Calidad) which links farmers to a few supermarket groups. On the supply side, CAPAC coordinates services provided to producers by different NGOs, which include contract management, quality control, and delivery to the supermarkets. On the demand side, CAPAC participates in national advocacy, the promotion of events, and the creation of labels. The supermarkets themselves have developed their own promotion, including a cooking school and books. And researchers at the International Potato Center developed improved storage methods (Thiele et al., 2011).

There have been multiple initiatives by lead private enterprises, coalitions of private interests, and public-private partnerships to promote the development of similar vertically coordinated value chains. Over the last 15 years, the World Bank Group has spent heavily in value chain development in West African countries with investments in infrastructure (roads, irrigation, electricity, market facilities), financing of private enterprises, support to producer organizations (training, capacity), development of supporting services (credit and insurance, 
technical assistance), and public sector capacity (extension, regulation). This has focused on value chains such as mangos, onions, meat, and poultry in Burkina Faso, and onions and rice in Senegal (World Bank Agricultural Diversification and Market Development Project for Burkina Faso and Senegal, internal documents). Rigorous evaluation of these investments is still not available.

These innovation platforms are to help actors in a value chain communicate and coordinate actions to address bottlenecks to value chain development. Swinnen (2018) emphasizes the role of identifying appropriate entry points that can consist in financing the lead firm in a value chain so it has resources to in turn finance farmers in interlinked contracts, and directly targeting constraints to value chain development such as farmer training, PO development, and presence of service providers. As revealed by the FARM Foundation's (2018) review of contracting in value chains in Sub-Saharan Africa, lead private sector enterprises have been important in acting as coordinating agents for value chain development. Coordination can thus be achieved at the cost of competition, creating an interesting trade-off whereby monopsony power in value chains can help facilitate vertical coordination while enhancing value extraction to the benefit of the lead agent.

Value chains for low-value domestic staple foods are particularly important for SHFs, but more difficult to develop as discipline is harder to achieve due to the large number of producers and availability of local buyers facilitating side-selling (Lançon, 2018). Yet, success with value chain development for domestic producers is essential if they are to remain competitive with imports, and also potentially help the country make headways in substituting for rapidly rising food imports.

Value chain development does not necessarily come top-down from commercial partners. It can also come bottom-up at the initiative of producer organizations. Collion (2018) thus contrasts top-down "aggregation schemes" in Morocco where an agroindustry contracts with producers to secure the provision of produce with quality specifications, to bottom-up "productive alliances" in Latin America where a producer organization develops a business plan that involves contracting with a commercial partner in resource-providing contracts. Capacity of the producer organization to do this typically comes with technical assistance and subsidies provided by the public sector and with the support of international development organizations (World Bank, 2016). Hence, the inclusive value chain development approach to modernization and transformation can come from upstream as well as from downstream agents in the value chain, even if the latter tends to dominate occurrences. 


\section{c. Inclusive value chains}

With SHF inclusion, value chain development can become not only a powerful instrument for modernization but also for rural poverty reduction via profit-making as entrepreneurs and via employment benefits as workers in vertically integrated schemes (Van den Broeck, Swinnen, and Maertens, 2016).

A value chain development approach to modernization typically builds on the best, starting with regions and farmers better endowed and closer to markets. As it gains strength, the value chain can gradually include more distant regions and less well-endowed farmers, fulfilling a more extensive poverty reduction function. Some of the key conditions for successful inclusion are the following:

(1) Sufficient asset endowments for SHF under the form of land, capital, health, knowledge and skills, and social capital to initiate production for the market and participation in a value chain (Devaux, Torero, Donovan, and Horton, 2016).

(2) Producer organizations with capacities, discipline, and bargaining power to engage in contracting with commercial partners in productive alliances, without the risks of side-selling and contract defaulting (World Bank, 2016).

(3) Willingness and capacity of commercial partners to contract with SHFs in resource providing contracts, or in cooperation with service-providing institutions such as commercial banks and technology companies that offer SHFs access to these resources (Swinnen et al., 2015).

(4) Quality recognition sufficiently upstream in the value chain that it creates incentives for SHF to certify their goods and engage in quality improvement in their production practices (Bernard et al., 2017).

(5) Helping SHF identify the comparative advantages they can build upon in developing a value chain inclusion strategy and achieving competitiveness. This can often be based on laborintensive activities anchored in traditional farming systems and agro-ecological niches, and on complementarities between small and large farms in servicing a value chain (Swinnen, 2018).

(6) Insertion of a value chain development effort in a broader rural development strategy pursuing agricultural and rural transformations such as formulated by the Agricultural Transformation Agency in Ethiopia (ATA, 2019) and in the Strategic Plan for Agriculture Transformation in Rwanda. This includes infrastructure investments to connect often remote areas to deep markets where they can be competitive (Schejtman and Berdegué, 2004).

As this long list of conditions indicates, value chain inclusion is difficult to achieve and requires both commitment by supporting agencies and sustained assistance to achieve results. It also requires a good understanding of the market forces that determine supply and demand for any particular product and hence the profit to be made in participation to the value chain. An early experiment illustrates the case: the Fair Trade value chain was designed to provide price and other supports to SHF. But Ruben and Fort (2012) find only modest direct income and production effects among coffee farmers and the early benefits potentially generated by Fair Trade contracts tend to be eroded by unlimited entry (de Janvry, McIntosh, and Sadoulet, 2015). 
Demand-driven resource-providing contracts and vertical coordination in value chains can thus be effective instruments for modernization. The incentives created by linking farmers to markets and overcoming market failures help endogenize technological and institutional responses. Design and implementation of this approach to modernization and transformation is still in need of much experimental research.

\section{d. Methodological options for impact evaluation of a demand-side approach}

Assessing the impact of a vertically coordinated value chain on (say) farmers production or welfare is particularly challenging. All impact evaluations proceed from well-defined units (composed of producers) that are treated (benefit from the intervention) and corresponding counterfactual that did not receive the treatment. In the case of value chains, the unit of intervention is most often either a farmer organization or a community, rather than an individual farmer. Even if not all farmers from a community participate in the value chain, this would be by choice, and hence non-participating farmers cannot be good counterfactuals to participating farmers. Any analysis will thus compare communities in which the value chain has intervened to communities not affected. This raises some statistical concerns. The number of communities any such intervention can incorporate is limited, simply because of financial and human resource constraints.

The second challenge is to find counterfactual communities. The gold standard for measuring the impact of interventions or programs is the randomized control trial. This would consist on defining a priori a set of communities that would equally qualify for participating to the value chain and only randomly invite half of them to participate. Getting an institution or a private sector firm to select in this way clients with whom it will do business is difficult. But getting a large number of private and public sector partners to all agree around a scheme that will impose on them restrictions on who should and should not be incorporated in the process of value chain construction is even more challenging. In addition, the construction of a value chain is by essence gradual, and it is in part adjusted to the needs and with the contributions of the communities that are incorporated. It is rarely a blue print that is offered to communities.

It is consequently not surprising that we find almost no rigorous impact evaluations of value chains. Those that exist proceed with an ex-post evaluation whereby researchers take stock of the communities that are included in the value chain and look for similar communities that are not included. Cavatassi et al. (2011) provide an interesting example with evaluation of a value chain linking smallholder potato farmers in the mountain regions of Ecuador to high-value markets. The authors proceed with a careful matching of communities, including propensity score matching using census data, verification by key local organizations and agronomists to determine whether they were comparable, and finally verifying that the treated and control communities did not differ regarding other interventions. Their impact evaluation is thus restricted to less than half of the treatment communities (18) for which they have a good counterfactual. The authors then use different methods of weighting participants, nonparticipants, and control farmers. All of them show similar results showing that the value chain has brought a large increase in yield and in gross value per hectare, and that these benefits were obtained through both selling a higher percentage and quantity of potato harvest and selling at a 30 per cent higher price. Production costs also increased but increased revenues outweigh added costs, suggesting welfare benefits for the farmers.

Impact analysis of contract farming presents somewhat different challenges, but is generally 
easier to do. Similar to what has been done to evaluate the impact of microfinance institutions (for example by Banerjee et al., 2015a), one can imagine a large processor who is extending its scale of operation willing to proceed with a randomized scheme, by which it will preselect more units (farmers or villages) than it wants to incorporate, or use a phased-in design whereby selected units are randomly assigned to be incorporated in two phases. Yet, the large literature attempting to measure the impact of contract farming on farmer welfare uses observational methods (Barrett et al., 2012; Bellemare and Bloem, 2018). Most studies use propensity score matching to find counterfactuals to individual participating farmers, often within limited samples of non-participating farmers. The validity of the method in that context is questionable as identification of treatment effects is based on the assumption that selection into participation is fully captured by observable characteristics. As of yet, the closest to a randomized evaluation of getting smallholders access to high value markets through contract farming was done by Ashraf et al. (2009). The authors worked with an NGO that serves as an intermediary linking SHF to commercial banks, retail providers of farm inputs, transportation services, and exporters. 36 farmer groups selected to participate in the experiment were randomized into treatment and control. The study shows that during the first year of operation, the contract increased production of export crops and lowered marketing costs, leading to a $32 \%$ income gain for new adopters. The experience however fell apart one year into the project, with defaulting on their commitments by buyers and farmers. It consequently has little external validity for what contract farming by a solid private sector partner could do (Bellemare and Bloem, 2018).

In view of the difficulty of organizing experiments on value chains, using natural experiments or statistical instrumentation can to be a fruitful approach. Macchiavello and Morjaria (2015) thus use an exogenous negative supply shock of Kenyan rose exports on the Dutch market due to post-electoral violence to study the importance of relational contracting when contract enforcement is weak. They show that Kenyan exporters selectively allocated limited deliveries across contracts to maintain credibility in seller's reliability. In a study of relational contracts in the Rwandan coffee industry, the same authors (2019) instrument the placement of mills to show that more potential competition from other mills reduces the use relational contracts with farmers making farmers worse off and reducing the quantity of coffee supplied to mills. Second-best competition is thus not necessarily welfare reducing.

\section{Conclusion}

With use of Agriculture for Development lagging in spite of its recognized importance for growth, agricultural and rural transformations, and poverty reduction in agriculture-based countries, efforts have been made to unleash an Agriculture-for-Development sequence using both supply- and demand-side approaches to constraint removal and inclusive value chain development. The supply-side approach has focused on removing major obstacles to adoption originating in liquidity, risk, information, and markets. It has yielded significant benefits, especially in terms of designing institutional innovations to overcome constraints to adoption, and work is still in progress. Institutional agents such as governments, international and bilateral development agencies, NGOs, and donors have a key role to play in implementing the approach. Yet, the approach has shown limits with modest aggregate success in technology adoption, stressing the need for a complementary approach. A demand-side approach that relies on the development of value chains and SHF inclusion has been relatively less explored in spite of potential effectiveness. This approach focuses on creating incentives to modernization in 
inclusive value chains that cater through commercial agents to well identified consumer demand. Success typically requires technological and institutional innovations to meet this demand through the value chain. Private agents such as entrepreneurs and corporations, and collective action in producer organizations, have a key role to play in designing and implementing contracts and coordination to achieve competitiveness. Important lessons from experiences reviewed highlight the roles of asset endowments, producer organizations, contracting, and value chain coordination through lead agents and multi-stakeholder platforms. Implementation of both approaches to achieve growth and poverty reduction requires increasing investment in the Agriculture for Development sequence.

Together, these recommendations help define a research agenda to be followed in support of the much needed use of Agriculture for Development in poor agriculture-based countries. ${ }^{*}$ For the supply-side approach, the agenda focuses on identifying technological and institutional innovations to overcome the credit, insurance, information, and market access constraints to adoption. For the demand-side approach, it focuses on promoting value chain development and inclusion with attention to the roles of threshold asset endowments, designing and implementing resource-providing contracts, enhancement of PO discipline in contracting, technological and institutional innovations for SHF to be competitive in meeting effective consumer demand, and achieving coordination in value chains that favors inclusion and a fair sharing of value. While considerable experience has been gained in rigorous evaluations of the supply-side approach, conceptual thinking is still needed to achieve a similar level of rigor in evaluating the demand-side approach.

\footnotetext{
* See also the useful research agenda on agri-food value chains proposed by Barrett, Reardon, Swinnen, and Zilberman (2019).
} 


\section{References}

Abate, G., \& Bernard, T. (2018). "Lemons markets in African agriculture: Wheat in Ethiopia." Working paper, Economics Department, University of Bordeaux.

Adelman, I. (1984). "Beyond export-led growth." World Development, 12(9), 937-49.

Aggarwal, S., Giera, B., Jeong, D., Robinson, J., \& Spearot, A. (2018a). "Market Access, Trade Costs, and Technology Adoption: Evidence from Northern Tanzania." Working paper, Department of Economics, UC Santa Cruz.

Aggarwal, S., Francis, E., and Robinson, J. (2018b). "Grain today, gain tomorrow: Evidence from a storage experiment with savings clubs in Kenya." Journal of Development Economics, 13(C), 1-15.

Aker, J., Ghosh, I., \& Burrell, J. (2016). "The promise (and pitfalls) of ICT for agriculture initiatives." Agricultural Economics, 47(S1), 35-48.

Aker, J. (2010). "Information from markets near and far: Mobile phones and agricultural markets in Niger." American Economic Journal: Applied Economics, 2(3), 46-59.

Alston, J., Pardey, P., James, J., \& Andersen, M. (2009). "A Review of Research on the Economics of Agricultural R\&D." Annual Review of Resource Economics, 1, 537-565.

Anderson, J., and Feder, G. (2007). "Agricultural extension." In Evenson, R., \& Pingali, P. (eds.), Handbook of Agricultural Economics, Chapter 44, Volume 3, Agricultural Development: Farmers, Farm Production, and Farm Markets. Amsterdam: Elsevier.

Ashraf, N., Gine, X., \& Karlan, D. (2009). "Finding missing markets (and a disturbing epilogue): Evidence from an export crop adoption and marketing intervention in Kenya." American Journal of Agricultural Economics, 91(4), 973-990.

ATA. (2019). Agricultural Transformation Agency, Annual Report 2017-18. http://www.ata.gov.et/

ATAI. (2018). "Evidence for transformation: Framing a research agenda in agriculture for development." CEGA, University of California at Berkeley.

Bairoch, P. (1973). "Agriculture and the industrial revolution, 1700-1914.” In Cipolla, C. (ed.), The Fontana Economic History of Europe: The Industrial Revolution, Vol. 3, 452-506. London: Collins/Fontana books.

Banerjee, A., Breza, E., Chandrasekhar, A., \& Golub, B. (2018). "When less is more: Experimental evidence on information delivery during India's demonetization." Working paper, Economics Department, MIT.

Banerjee, A., Duflo, E., Goldberg, N., Karlan, D., Osei, R., Parienté, W., Shapiro, J., Thuysbaert, B., \& Udry, C.. (2015a). "A multifaceted program causes lasting progress for the very poor: Evidence from six countries." Science, 348(6236), 1260799-16.

Banerjee, A., Duflo, E., Glennerster, R., \& Kinnan, C. (2015b). "The miracle of microfinance? Evidence from a randomized evaluation." American Economic Journal: Applied Economics, 7(1), 22-53.

Bardhan, P. (1989). The Economic Theory of Agrarian Institutions. Oxford: Clarendon Press.

Barrett, C., \& Carter, M. (2012). "The economics of poverty traps and persistent poverty: Policy and empirical implications." Working paper, Dyson School of Applied Economics and Management, Cornell University.

Barrett, C., Bachke, M., Bellemare, M., Michelson, H., Narayanan, S., \& Walker, T. (2012). "Smallholder Participation in Contract Farming: Comparative Evidence from Five Countries." World Development, 40(4), 715-730.

Barrett, C., Reardon, T., Swinnen, J., \& Zilbermam, D. (2019) "Structural Transformation and Economic Development: Insights from the Agri-food Value Chain Revolution." Working paper, Dyson School of Applied Economics and Management, Cornell University. 
Beaman, L., Ben Yishay, A., Magruder, J., \& Mobarak, A.M. (2018). "Can Network TheoryBased Targeting Increase Technology Adoption?" ATAI Working Paper, CEGA, University of California at Berkeley.

Beaman, L., Karlan, D., Thuysbaert, B., \& Udry, C. (2015). "Self-Selection into Credit Markets: Evidence from Agriculture in Mali." https://www.povertyactionlab.org/sites/default/files/publications/361\%20Self\%20Selectio n\%20Mali\%20May2015.pdf.

Bellemare, M., \& Bloem, J. (2018). "Does contract farming improve welfare? A review." World Development, 112, 259-71.

Bellemare, M., \& Lim, S. (2018). "In All Shapes and Colors: Varieties of Contract Farming." Applied Economic Perspectives and Policy, 40(3), 379-401.

Bellemare, M. (2015). "Contract farming: What's in it for smallholder farmers in developing countries?" Choices, 30(3), 1-4.

BenYishay, A., \& Mobarak, A.M. (2019). "Social learning and incentives for experimentation and communication." The Review of Economic Studies, 86(3), 976-1009.

Bergquist, L. (2017). "Pass-through, Competition, and Entry in Agricultural Markets: Experimental Evidence from Kenya." Working Paper, Economics Department, University of Michigan.

Bernard, T., de Janvry, A., Mbaye, S., \& Sadoulet, E. (2017). "Expected Product Market Reforms and Technology Adoption by Senegalese Onion Producers." American Journal of Agricultural Economic, 99(4), 1096-1115.

Bhargava, A., Vagen, T., \& Gassner, A. (2018). "Breaking Ground: Unearthing the Potential of High-resolution, Remote-sensing Soil Data in Understanding Agricultural Profits and Technology Use in Sub-Saharan Africa." World Development, 105(C), 352-66.

Boettiger, S., Denis, N., \& Sanghvi, S. (2017). "Readiness for agricultural transformation." https://www.mckinsey.com/industries/chemicals/our-insights/readiness-for-agriculturaltransformation

Bold, T., Kaizzi, K., Svensson, J., \& Yanagizawa-Drott, D. (2017). "Lemon Technologies and Adoption: Measurement, Theory and Evidence from Agricultural Markets in Uganda." The Quarterly Journal of Economics, 132(3), 1055-1100.

Boucher, S., Carter, M., \& Guirkinger, C. (2008). "Risk Rationing and Wealth Effects in Credit Markets: Implications for Agricultural Development." American Journal of Agricultural Economics, 90(2), 409-23.

Bridle, L., Magruder, J., McIntosh, C., \& Suri, T. (2019). "Experimental Insights on the Constraints to Agricultural Technology Adoption." Working paper, Agricultural Technology Adoption Initiative, J-PAL (MIT) and CEGA (UC Berkeley).

Burke, M., Falcao Bergquist, L., \& Miguel, E. (2019). "Sell Low and Buy High: An Arbitrage Puzzle." Quarterly Journal of Economics, 134(2), 785-842.

Burke, W., Jayne, T., \& Black, R. (2017). "Factors explaining the low and variable profitability of fertilizer application to maize in Zambia." Agricultural Economics, 48(1), 115-26.

Bustos, P., Caprettini, B., \& Ponticelli, J. (2016). "Agricultural Productivity and Structural Transformation. Evidence from Brazil.” American Economic Review, 106(6), 1320-65.

Byerlee, D., \& Haggblade, S. (2013). "African Food Systems to 2030: Toward Inclusive Business Models." Working paper, Center on Food Security and the Environment, Stanford University.

Cai, J., de Janvry, A., \& Sadoulet, E. (2020). "Subsidy Policies and Insurance Demand." American Economic Review, forthcoming.

Cai, J. (2016). "The impact of insurance provision on households' production and financial decisions." American Economic Journal Economic Policy, 8(2), 44-88. 
Carter, M., de Janvry, A., Sadoulet, E., \& Sarris, A. (2017). "Index Insurance for Developing Country Agriculture: A Reassessment." Annual Review of Resource Economics, 9, 421-38.

Carter, M., \& Barrett, C. (2006). "The Economics of Poverty Traps and Persistent Poverty: An Asset-based Approach.” Journal of Development Studies, 42(2),178-99.

Carter, M., Laajaj, R., \& Yang, D. (2013). "The Impact of Voucher Coupons on the Uptake of Fertilizer and Improved Seeds: Evidence from a Randomized Trial in Mozambique." American Journal of Agricultural Economics, 95(5), 1345-51.

Casaburi, L., \& Willis, J., (2018). "Time versus state in insurance: Experimental evidence from contract farming in Kenya." American Economic Review, 108(12), 3778-813.

Casaburi, L., \& Reed, T. (2017). "Competition in Agricultural Markets: An Experimental Approach.” Working Paper, ATAI, CEGA, University of California at Berkeley.

Casaburi, L., Glennerster, R., \& Suri, T. (2013). "Rural Roads and Intermediated Trade: Regression Discontinuity Evidence from Sierra Leone." Working Paper, ATAI, CEGA, UC Berkeley.

Casaburi, L., Glennerster, R., Kamara, S., \& Suri, T. (2014). "Providing Collateral and Improving Product Market Access for Smallholder Farmers: A Randomized Evaluation of Inventory Credit in Sierra Leone.” 3ie Impact Evaluation Report 14.

Cavatassi, R., González-Flores, M., Winters, P., Andrade-Piedra, J., Espinosa, P., \& Thiele, G. (2011). "Linking smallholders to the new agricultural economy: The case of the plataformas de concertación in Ecuador." Journal of Development Studies, 47(10), 154573.

Chassang, S., Dupas, P., \& Snowberg, E. (2019). "Mechanism Design Meets Development: Selective Trials for Technology Adoption. Evidence from Kenya." Working paper, Economics Department, Stanford University.

Christiaensen, L., \& Todo, Y. (2014). "Poverty Reduction During the Rural-Urban Transformation - The Role of the Missing Middle. " World Development, 63(C), 43-58.

Christiaensen, L. (2017). "Agriculture in Africa-Telling myths from facts: A synthesis." Food Policy, 67, 1-11.

Cole, S., \& Fernando, N. (2016). "The Value of Advice: Evidence from the Adoption of Agricultural Practices.” Working paper, Harvard Business School, Cambridge MA.

Cole, S., Giné, X., Tobacman, J., Topolova, P., Townsend, R., \& Vickery, J. (2013). "Barriers to household risk management: Evidence from India." American Economic Journal Applied Economics, 5(1),104-35.

Collier, P., \& Dercon, S. (2015). "African agriculture in 50 years: Smallholders in a rapidly changing world?" FAO expert meeting on How to Feed the World in 2050, Rome.

Collion, M-H. (2018). "Inclusive value chains." Working paper, FERDI, Clermont-Ferrand.

Crépon, B., Devoto, F., Duflo, E., \& Pariente, W. (2015). "Estimating the Impact of Microcredit on those who Take it Up: Evidence from a Randomized Experiment in Morocco." American Economic Journal: Applied Economics, 7(1), 123-50.

Dalrymple, D. (2008). "International agricultural research as a global public good: Concepts, the CGIAR experience, and policy issues." Journal of International Development, 20(3), 347-79.

Dar, M., de Janvry, A., Emerick, K., Kelley, E., \& Sadoulet, E. (2019). "Inducing demand for information in social networks to promote technology adoption: An alternative approach to extension ." VoxEU May 19, https://voxeu.org/article/side-side-demonstrations-persuadefarmers-adopt-new-technologies

Das, N., de Janvry, A., \& Sadoulet, E. (2019). "Credit and Land Contracting: A Test of the Theory of Sharecropping." American Journal of Agricultural Economics, https://doi.org/10.1093/ajae/aaz005 
de Janvry, A., Duquennois, C., \& Sadoulet, E. (2018). "Labor Calendars and Rural Poverty: A case study for Malawi." Working Paper, University of California at Berkeley.

de Janvry, A., McIntosh, C., \& Sadoulet, E. (2015). "Fair Trade and Free Entry: Can a Disequilibrium Market Serve as a Development Tool?" Review of Economics and Statistics, 97(3), 567-73.

Dercon, S., \& Christiaensen, L. (2011). "Consumption risk, technology adoption, and poverty traps: evidence from Ethiopia." Journal of Development Economics, 96(2), 159-73.

Devaux, A., Torero, M., Donovan, J., \& Horton, D. (2016). "Innovation for inclusive value chain development: Successes and challenges.” IFPRI Synopsis, Washington DC.

Dewey, K. (2017). "The Challenges and Opportunities of Transforming African Agriculture." Annual Bank Conference on Africa (ABCA), UC Berkeley, June 1-2.

Dihel, A., Hollweg, C., \& Slany, A. (2018). "How does participation in value chains matter to African farmers?" World Bank Policy Research Paper 8506, Washington D.C.

Dillon, B., \&, Chelsey, D. (2016). "How Competitive are Food Crop Markets in Sub-Saharan Africa?" American Journal of Agricultural Economics, 99(5), 1344-61.

Duflo, E., Kremer, M., \& Robinson, J. (2008). "How High are Rates of Return to Fertilizer? Evidence from Field Experiments in Kenya.” American Economics Review, 98(2), $482-88$.

Emerick, K., de Janvry, A., Sadoulet, E., \& Dar, M. (2016). "Technological innovations, downside risk, and the modernization of agriculture." American Economic Review,106(6), 1537-1561.

Emerick, K., \& Dar, M. (2019). "Enhancing the diffusion of information about agricultural technology." Working paper, Economics Department, Tufts University.

Eswaran, M., \& Kotwal, A. (1986). "Access to Capital and Agrarian Production Organization." The Economic Journal, 96(382), 482-98.

Fafchamps, M., \& Minten, B. (2012). "Impact of SMS-Based Agricultural Information on Indian Farmers." The World Bank Economic Review, 26(3), 383-414.

FARM Foundation. (2018). "Contractualiser avec les agriculteurs en Afrique." www.fondation-farm.org, Paris.

Feder, G., Murgai, R., \& Quizon, J. (2004). "The Acquisition and Diffusion of Knowledge: The Case of Pest Management Training in Farmer Field Schools, Indonesia." Journal of Agricultural Economics, 55(2), 221-43.

Foster, A., \& Rosenzweig, M. (1995). "Learning by Doing and Learning from Others: Human Capital and Technical Change in Agriculture." Journal of Political Economy, 103(6), 11761209.

Foster, A., \& Rosenzweig, M. (2010). "Microeconomics of Technology Adoption.” Annual Review of Economics, 2(1), 395-424.

Giné, X., \& Yang, D. (2009). "Insurance, credit, and technology adoption: A field experiment in Malawi." Journal of Development Economics, 89(1), 1-11.

Gollin, D., Lagakos, D., \& Waugh, M. (2014). “The Agricultural Productivity Gap.” Quarterly Journal of Economics, 129(2), 939-93.

Goyal, A., \& Nash, J. (2016). Reaping richer returns: Public spending priorities for African agriculture productivity growth. Washington D.C.: World Bank Group.

Hasanain, A., Khan, Y., \& Rezaee, A. (2016). "Crowdsourcing government accountability: Experimental evidence from Pakistan.” Working Paper, Department of Agricultural and Resource Economics, University of California at Davis.

Huang, J. (2016). "Fostering Inclusive Rural Transformation in China and Other Developing Countries in Asia." Working Paper, Center for Chinese Agricultural Policy and Peking University, Beijing.

IFAD. (2016). Rural Development Report 2016: Fostering inclusive rural transformation. International Fund for Agricultural Development, Rome. 
IFPRI. (2018). Agricultural science and technology indicators data. International Food Policy Research Institute, Washington D.C..

Islam, M. (2014). "Can a Rule-of-Thumb Tool Improve Fertilizer Management? Experimental Evidence from Bangladesh.” Working Paper, CEGA-ATAI, UC Berkeley.

Jayne, T., Chamberlin, J., \& Benfica, R. (2018). "Africa's unfolding economic transformation." Journal of Development Studies, 54(5), 777-87.

Jensen, R. (2007). "The digital provide: Information (technology), market performance, and welfare in the South Indian fisheries sector." The Quarterly Journal of Economics, 122(3), 879-924.

Kabunga, N., Mogues, T., Bizimungu, E., Erman, A., \& Van Campenhout, B. (2016). "The State of Public Service Delivery in Uganda: Report of a Baseline Survey." Working Paper, International Food Policy Research Institute, Washington D.C..

Kalibwani, R., \& Twebaze, J. (2015). "Can an innovation platform succeed as a cooperative society? The story of Bubaare Innovation Platform Multipurpose Cooperative Society Ltd." In Iddo Dror et al., eds, Innovation Platforms for Agricultural Development (pp. 86-108). London: Routledge.

Karlan, D., Osei, R., Osei-Akoto, I., \& Udry, C. (2014). “Agricultural decisions after relaxing credit and risk constraints." Quarterly Journal of Economics, 129(2), 597-652.

Laajaj, R., Macours, K., Masso, C., Thuita, M., \& Vanlauwe, B. (2018). "Yield gap or field gap? Reconciling yield gains in agronomic trials and African smallholder conditions." Working paper, Paris School of Economics, Paris.

Lagakos, D., Mobarak, M., \& Waugh. M. (2018). "The Welfare Effects of Encouraging RuralUrban Migration.” NBER Working Paper No. 24193.

Lançon, F. (2018). “Agricultural Value chains inclusiveness and domestic demand." Working Paper, CIRAD, Montpellier.

Lane, G. (2018). "Credit lines as insurance: Evidence from Bangladesh." Working Paper, Department of Agricultural and Resource Economics, UC Berkeley.

Lewis, A. (1954). "Economic development with unlimited supplies of labor." The Manchester School of Economic and Social Studies, 22(2), 139-91.

Macchiavello, R., \& Morjaria, A. (2015). "The Value of Relationships: Evidence from a Supply Shock to Kenyan Rose Exports.” American Economic Review, 105(9), 2911-45.

Macchiavello, R., \& Morjaria, A. (2019). "Competition and Relational Contracts in the Rwanda Coffee Chain." CEPR Discussion Papers 13607.

Maccini, S., \& Yang, D. (2009). "Under the Weather: Health, Schooling, and Economic Consequences of Early-Life Rainfall.” American Economic Review, 99(3), 1006-26.

Magruder, J. (2018). "An assessment of experimental evidence on agricultural technology adoption in developing countries." Annual Review of Resource Economics, 10, 299-316.

Marenya, P., \& Barrett, C. (2009). "State-conditional fertilizer yield response on western Kenyan farms.” American Journal of Agricultural Economics, 91(4), 991-1006.

McCullough, E. (2017). "Labor productivity and employment gaps in Sub-Saharan Africa." Food Policy, 67, 133-52.

McIntosh, C., Povel, F., \& Sadoulet, E. (2018). "Utility, risk, and demand for incomplete insurance: Lab experiments with Guatemalan cooperatives." Economic Journal, forthcoming.

Mellor, J. (1995). Agriculture on the road to industrialization. Washington D.C.: International Food Policy Research Institute.

Mobarak, M., \& Rosenzweig, M. (2013). "Risk, insurance, and wages in general equilibrium." Working Paper, Department of Economics, Yale University, New Haven, Conn.

Page, J. (2018). "Uganda lecture: Beyond manufacturing." Working Paper, The Brookings Institution, Washington D.C. 
Pardey, P., Andrade, R., Hurley, T., Rao, X., \& Liebenberg, F. (2016). "Returns to food and agricultural R\&D investments in Sub-Saharan Africa, 1975-2014." Food Policy, 65(C), 18.

Ragasa, C., and Niu, C. (2017). "The state of agricultural extension and advisory services provision in Malawi: Insights from household and community surveys." Working Paper, International Food Policy Research Institute, Washington D.C..

Reardon, T., Swinnen, J., Barrett, C., \& Berdegué, J. (2009). "Agrifood Industry Transformation and Small Farmers in Developing Countries.” World Development, 37(11), 1717-27.

Rodrik, D., McMillan, M., \& Sepúlveda, C. (2016). "Structural Change, Fundamentals, and Growth." In Margaret McMillan, Dani Rodrik, and Claudia Sepúlveda (eds.). Structural Change, Fundamentals, and Growth. Washington DC: IFPRI.

Rodrik, D. (2015). "Premature Deindustrialization." NBER Working Paper No. 20935.

Rosenzweig, M., \& Wolpin, K. (1993). "Credit Market Constraints, Consumption Smoothing, and the Accumulation of Durable Production Assets in Low-Income Countries: Investments in Bullocks in India.” Journal of Political Economy, 101(2), 223-244.

Ruben, R., \& Fort, R. (2012). "The Impact of Fair Trade Certification for Coffee Farmers in Peru." World Development, 40(3), 570-82.

Saenger, C., Torero, M., \& Qaim. M. (2014). "Impact of third-party contract enforcement in agricultural markets-A field experiment in Vietnam." American Journal of Agricultural Economics, 96(4), 1220-38.

Schejtman, A., \& Berdegué, J. (2004). "Rural Territorial Development." Rimisp-Centro Latinoamericano para el Desarrollo Rural. Santiago, Chile.

Schickele, A. (2016). "Make it Rain." Cambridge, MA: Abdul Latif Jameel Poverty Action Lab, Center for Effective Global Action, and Agricultural Technology Adoption Initiative.

Schultz, T.W. (1964). Transforming Traditional Agriculture. New Haven: Yale University Press.

Shee, A., Turvey, C., \& You, L. (2018). "Design and Rating of Risk-Contingent Credit for Balancing Business and Financial Risks for Kenyan Farmers." 2018 Conference of the International Association of Agricultural Economists.

Stiglitz, J. (2018). "From Manufacturing-Led Export Growth to a 21stCentury Inclusive Growth Strategy: Explaining the Demise of a Successful Growth Model and What To Do About It." Working Paper, UNU-WIDER, Helsinki.

Svensson, J., \& Yanagizawa, D. (2009). "Getting prices right: the impact of the market information service in Uganda." Journal of the European Economic Association, 7(2-3), 435-45.

Swinnen, J., Deconinck, K., Vandemoortele, T., \& Vandeplas, A. (2015). Quality standards, value chains, and international development. Cambridge, U.K.: Cambridge University Press.

Swinnen, J. (2018). "Inclusive Value Chains to Accelerate Poverty Reduction in Africa." Working Paper, Economics Department, Leuven University.

Tarozzi, A., Desai, J., \& Johnson, K. (2013). "On the impact of microcredit: Evidence from a randomized intervention in rural Ethiopia." Working Paper, Department of Economics and Business, Pompeu Fabra University, Barcelona.

Thiele, G., Devaux, A., Reinoso, I., Pico, H., Montesdeoca, F., Pumisacho, M., AndradePiedra, J., Velasco, C., Flores, P., Esprella, R., \& Thomann, A. (2011). "Multi-stakeholder platforms for linking small farmers to value chains: evidence from the Andes." International Journal of Agricultural Sustainability, 9(3), 423-33. 
Tjernström, E. (2017). "Signals, Similarity, and Seeds: Social Learning in the Presence of Imperfect Information and Heterogeneity." Department of Agricultural and Applied Economics, University of Wisconsin, Madison.

Van den Broeck, G., Swinnen, J., \& Maertens, M. (2016). "Global Value Chains, Large-Scale Farming, and Poverty: Long-Term Effects in Senegal." Licos discussion papers series, Leuven University.

Vendercasteelen, J., Beyene, S., Minten, B., \& Swinnen, J. (2018). "Big cities, small towns, and poor farmers: Evidence from Ethiopia." World Development, 106, 393-406.

World Bank. (2007). World Development Report-Agriculture for Development. Washington D.C.: The World Bank.

World Bank. (2016). Linking farmers to markets through productive alliances. Washington D.C.: The World Bank. 

"Sur quoi la fondera-t-il l'économie du monde qu'il veut gouverner? Sera-ce sur le caprice de chaque particulier? Quelle confusion! Sera-ce sur la justice? Il l'ignore."

Pascal

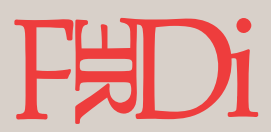

Created in 2003, the Fondation pour les études et recherches sur le développement international aims to promote a fuller understanding of international economic development and the factors that influence it.

\section{$\rightarrow$ Contact}

www.ferdi.fr

contact@ferdi.fr

+33 (o)4 73177530 